\title{
Comparative Studies on Maturation Process of Secondary Ossification Centers of Long Bones in the Mouse, Rat, Dog and Monkey
}

\author{
Satoshi FUKUDA and Osamu MATSUOKA \\ Division of Radiation Hazards, National Institute of Radiological \\ Sciences, 4-9-1, Anagawa, Chiba-shi, 260 Japan.
}

(Received for publication: June 27, 1979)

\begin{abstract}
Comparative studies was made on the whole processes of maturation of the secondary ossification centers in the extremity in the mouse, rat, dog and monkey in order to determine points of similarity and difference among these species. The appearance and the union of the secondary ossification centers were observed to follow a common sequence and order in all the species examined. The total bone score was defined as the sum of the bone scores of respective secondary ossification centers over the observation period according to a set criteria. By plotting these indices against the chronological age it was shown in all of these species that the whole process of maturation of the secondary ossification centers in the long bone consisted of three biological stages as indicated by the three straight lines with different slopes. The first stage is considered to account for the appearance of the secondary ossification centers and their accelerated development at early period, while the second stage corresponds to the subsequent gradual development. The third stage represents a period where the ossification centers reach a complete or almost complete union to diaphysis. It is concluded that in the mouse, rat, dog and monkey the maturation processes of the secondary ossification centers follow the same growth consisting of three developmental stages and that each of these three stages provides a measure of comparison among these species.
\end{abstract}

\section{Introduction}

It is considered recommendable to use more than two species of animals if the results expected to be drawn from the experiment are intended to be applied to a human being. Because a same substance may produce different effects in the different species, comparative studies considering the species differences are necessary as a basis for such an experiment.

Many investigators have already reported on the secondary ossification centers in several experimental animals $[3,4,9,12$, $17,18]$. Comparative studies on the sequence of appearance and/or union of secon- day ossification centers have been carried out by Dawson on the rat and man [3], and by Johnson on the mouse, rat and man [9]. Many of them, however, described only the order and time of appearance and/or union to diaphysis $[3,4,9,12,18]$ and only a few studied on the whole processes of maturation of the secondary ossification centers of the so-called long bones in the extremities [17]. It is considered, therefore, that these published data are not sufficient to be used in comparison of the bone development in several animal species. In addition, a variety of criteria employed in these studies makes it diff- 
icult to compare the data both in quantitative and qualitative way.

The authors have reported on the whole processes of maturation of the secondary ossification centers in $\mathrm{C} 3 \mathrm{H}$ mouse [5], Wistar rat [7] and cynomolgus monkey (macaca fascicularis) [6]. These studies were carried out under a standard condition using same methodology and criteria to facilitate the comparison of developmental bones among these species. With the inclusion of the data on the beagle dog which were investigated by $\mathrm{H}$. Ichiki who used an identical method as ours [8], a comparative analysis was made on the whole processes of maturation of the secondary ossification centers in the four laboratory animals i. e. mouse, rat, dog and monkey, to identify points of similarity and difference.

\section{Materials and Methods}

The data for analysis on the development of secondary ossification centers in so-called long bones in the extremities were quoted from the author's previous reports for the mouse, rat and monkey $[5$, $6,7]$ and from the report by Ichiki [8], who used the same method and criteria as the author's, for the beagle dog.

The species, strain or breed, numbers of the animals used and time schedule of each examination are summerized in Table 1. The secondary ossification centers employed as indicators were supraglenoid tubercle of scapula, both epiphyses of humerus, radius, ulna, femur, tibia and fibula. A radiographic technique was used to evaluate the status of the secondary ossification centers in all species. The radiographic images of the development status of each secondary ossification centers were assessed based on the criteria proposed by Ohwada and Sutow [11], in which the whole process of maturation was divided into eleven steps, from 0 to 10, following the morphological changes. The sum of the designated number for each step of the criteria was termed as 'bone score'. The comparison of the whole processes of maturation of the secondary ossification centers among the four species was done by means of the method proposed by Acheson [1,2]. The procedure is as follows. In the first place the total bone scores are calculated to sum up the bone scores of the eleven kinds of secondary ossification centers which were commonly observed throughout the four species, from which were excluded the distal epiphysis of fibula and the supraglenoid tubercle of scapula at time point

Table 1. Animals and time schedule of examination

\begin{tabular}{|c|c|c|c|c|c|}
\hline Species & $\begin{array}{l}\text { Strain or } \\
\text { Breed }\end{array}$ & $\begin{array}{l}\text { Total number of } \\
\text { animals examined }\end{array}$ & $\begin{array}{l}\text { Observation } \\
\text { period }\end{array}$ & $\begin{array}{l}\text { Measuring time } \\
\text { points }\end{array}$ & $\begin{array}{l}\text { Numbers used at } \\
\text { each point }\end{array}$ \\
\hline $\begin{array}{l}\text { Mouse } \\
{[5]^{*}}\end{array}$ & $\mathrm{C} 3 \mathrm{H}$ & $\begin{array}{c}180 \\
\text { (M 90, F 90) }\end{array}$ & $\begin{array}{l}0 \text { to } 27 \text { weeks } \\
\text { old }\end{array}$ & $\begin{array}{l}\text { at interval of } 1 \text { or } \\
\text { several weeks }\end{array}$ & $\begin{array}{l}10 \text { animals } \\
(5 \text { each of male } \& \\
\text { female })\end{array}$ \\
\hline $\begin{array}{l}\text { Rat } \\
{[7]^{*}}\end{array}$ & Wistar & $\begin{array}{c}259 \\
\text { (M 130, F 129) }\end{array}$ & $\begin{array}{l}0 \text { to } 134 \text { weeks } \\
\text { old }\end{array}$ & $\begin{array}{l}\text { at interval of } 1 \text { or } \\
\text { several weeks }\end{array}$ & $\begin{array}{l}10 \text { animals } \\
\text { ( } 5 \text { each of male \& } \\
\text { female) }\end{array}$ \\
\hline $\begin{array}{c}\text { Dog } \\
{[8]^{*}}\end{array}$ & Beagle & (M 99, F 100) & $\begin{array}{l}0 \text { to } 14 \text { months } \\
\text { old }\end{array}$ & $\begin{array}{l}1 \text { day, } 1 \text { and } 2 \\
\text { weeks at every } \\
\text { month during } 1 \text { to } \\
6 \text { months, } 8,10,12 \text {, } \\
14 \text { months }\end{array}$ & $\begin{array}{l}10 \text { to } 24 \text { animals } \\
\text { including male } \\
\text { and female }\end{array}$ \\
\hline $\begin{array}{c}\text { Monkey } \\
{[6]^{*}}\end{array}$ & Cynomolgus & (M $47, \mathrm{~F} 51)$ & $\begin{array}{l}\text { About } 0.5 \text { to } \\
8.5 \text { years old }\end{array}$ & $\begin{array}{l}\text { at interval of half } \\
\text { year }\end{array}$ & $\begin{array}{l}1 \text { to } 6 \text { animals } \\
\text { male and female, } \\
\text { respectively }\end{array}$ \\
\hline
\end{tabular}

$\mathrm{M}$; male, $\mathrm{F}$; female. *shows reference number 
when the measurement was made. Those total bone scores were plotted against the chronological ages of the respective species.

Although the sex difference was not observed in the mouse, rat and dog $[5,7$, $8]$, it was demonstrated in the monkey [6]. The examination in the monkey, therefore, was done for the male and female, respectively.

\section{Results}

The whole processes of maturation of the secondary ossification centers of all the four species are shown in Fig. 1 which are presented in a same style. The figures on the mouse and the rat which were previously reported are included for comparison with those of the dog and the monkey. The axis of longitude of these figures represents the total bone scores. The axis of abscissa represents the chronological age, i. e., the measured time points. The points of similarities and differences among the four species with regard to the maturation processes of respective ossification were summerized as follows.

Supraglenoid tubercle of scapula Supraglenoid tubercle of scapula generally appeared early and developed to the complete union at extremely high speed. In the dog, only this portion united earlier than the other centers. The data of the monkey was lacking.

Proximal cpiphysis of humerus In all cases except for the female monkey this epiphysis rapidly developed from the time of appearance ( 1 step) to the 8 th step. In
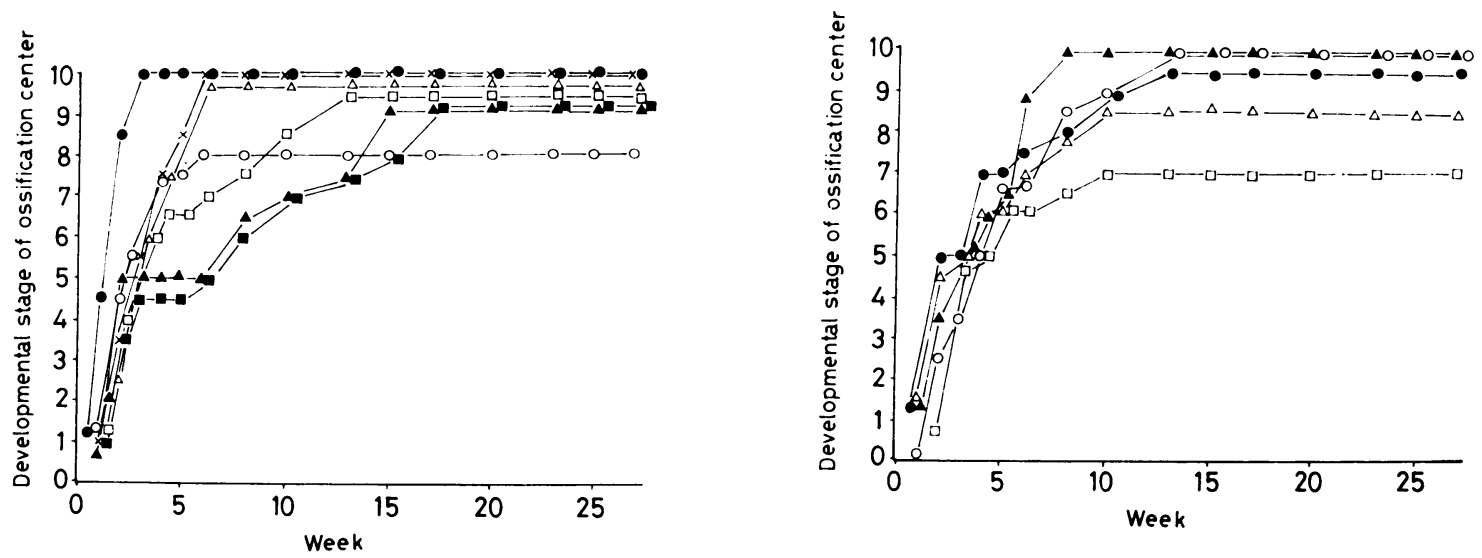

Fig. 1a Developmental processes of secondary ossification centers in the mouse. (right; fore limb, left; hind limb)
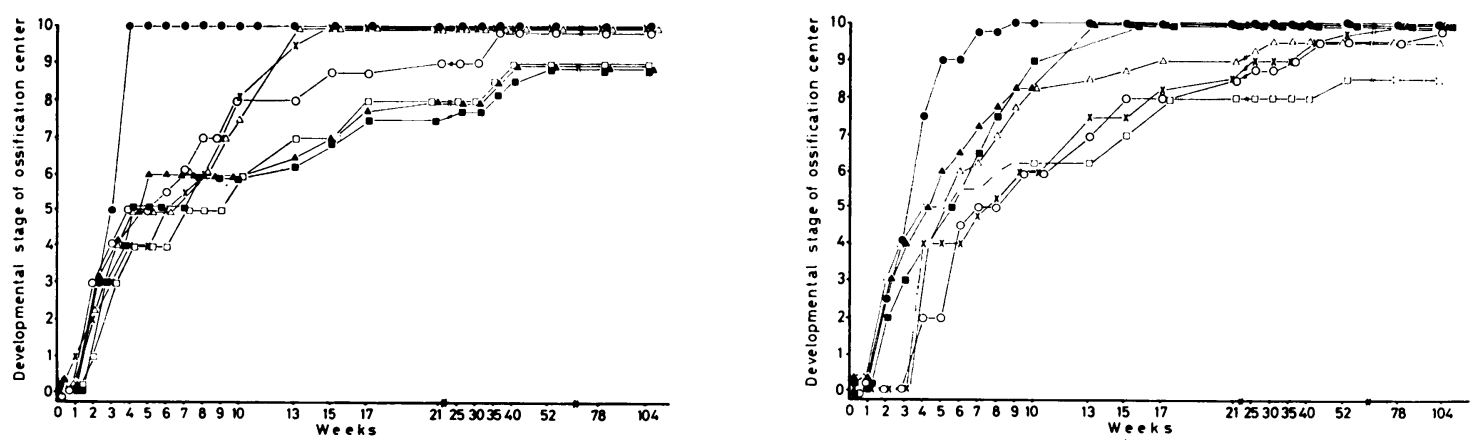

Fig. 1b Developmental processes of secondary ossification centers in the rat (right; fore limb, left; hind limb) 

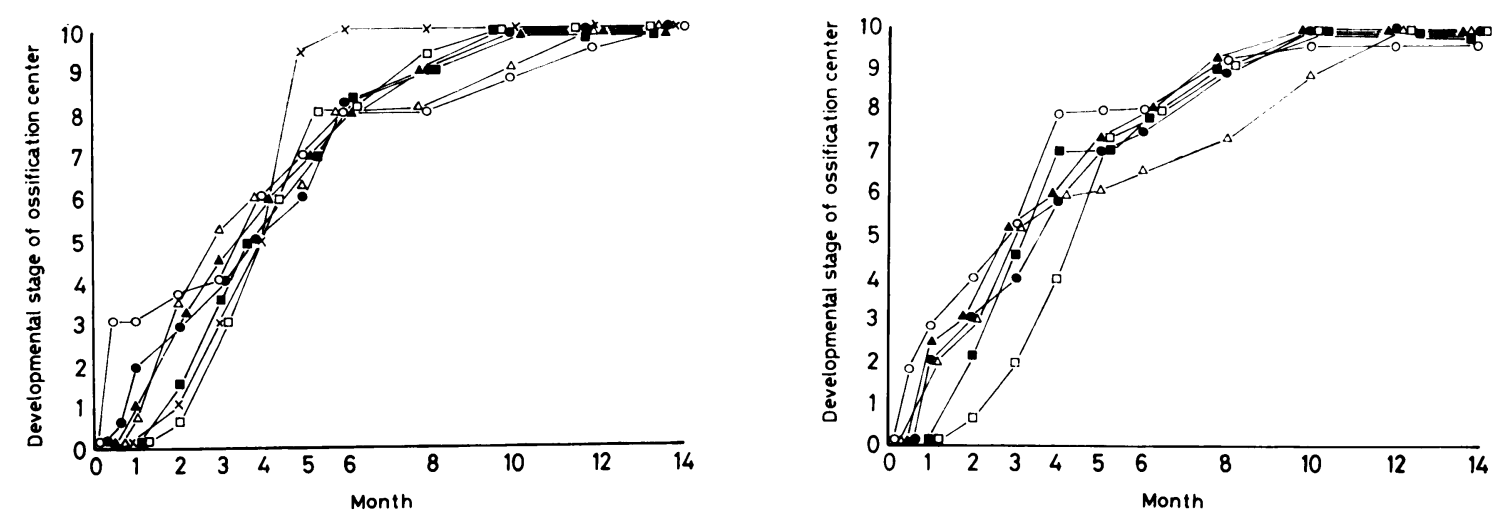

Fig. 1c Developmental processes of secondary ossification centers in the dog. (right; fore limb, left; hind limb)
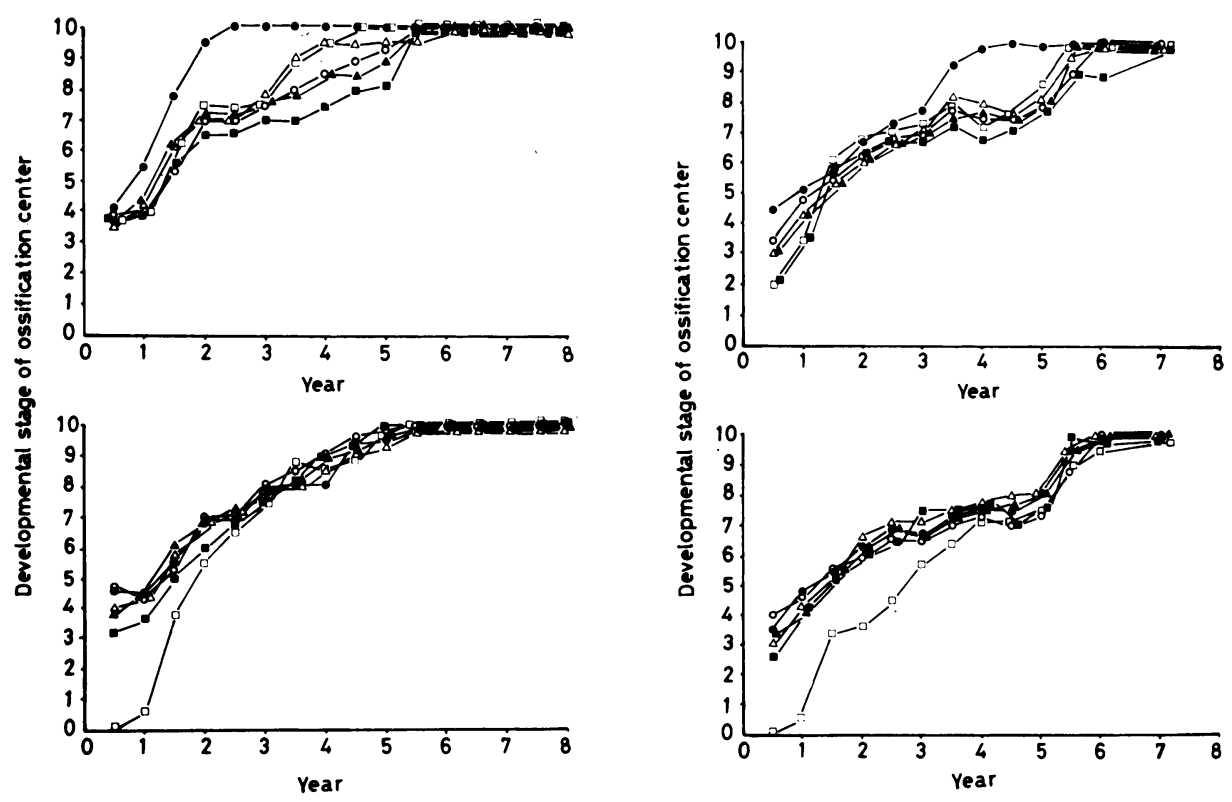

Fig. 1d Developmental processes of secondary ossification centers in the male monkey (right) and in the female monkey (left). (upper; fore limb, lower; hind limb)

fore limb

Supraglenoid tubercle $(x)$

Humerus p. e. ( $\bigcirc)$, d. e. (O)

Radius p. e. $(\triangle)$, d. e. ( $\Delta$ )

Ulna p. e. ( $\square$ ), d. e.

p. e.=proximal epiphysis hind limb

Great trochanter $(x)$

Femur p. e. ( $\bigcirc)$, d. e. (O)

Tibia p. e. $(\triangle)$, d. e. ( $\Delta)$

Fibula p. e. $(\square)$, d. e. ( $\square)$

, d.e. $=$ distal epiphysis

the rat it completed union at thirty five weeks. In the dog, the epiphysial line of this portion disappeared at fourteen months which was the latest among other ossification centers. The smooth and gradual development was observed in the male monkey in which it reached 8th step at three years and a half. The complete 
union was observed at six years. The development in the female monkey stopped temporary at 7 th step. The complete union was observed at five years and a half.

Distal epiphysis of humerus This ossification center appeared at very early time in all species. They developed rapidly to unite with diaphysis, which is especially evident in the mouse, rat and monkey. Therefore, the period from the appearance to the union is very short. The time of union occured at three weeks in the mouse and at four weeks in the rat, respectively. The developmet of the ossification centers in the dog was smooth with the speed similar to other species. In the monkey, this portion developed more rapidly than other centers. The union in the male monkey was observed at four years and a half.

Proximal epiphysis of radius The epiphysis of the mouse developed very rapidly, and completed at six weeks. In the rat it developed rapidly up to the 5 th step by four weeks. The cessation of the development was recognized between four and six weeks. Thereafter it developed to unite with diaphysis at thirteen weeks. In the dog, the portion was observed to develop smoothly up to the 8 th step at six months and developed thereafter more slowly till twelve months. In the male monkey, the development showed a constant speed up to the 8 th step, after which it was found almost not to proceed for the period between three and a half to five years. At six years this epiphysis was observed to unite with diaphysis completely. In the female on the other hand, it developed well up to the middle of the ninth step. A persisting epiphysial cartilage line continued to exist during the period of four to five years and a half. At six years this line of the epiphysial cartilage was obliterated both in the male and the female.

Distal epiphysis of radius This epiphysis, firstly, acceleratedly developed up to the
5 th step in the mouse, and 6 th step in the rat, respectively. The development ceased during period from two to six wee$\mathrm{ks}$ in the mouse, and from five to ten weeks in the rat. These epiphyses finally remained at the 9 th step without obliterating the epiphyseal cartilage lines both in the mouse and the rat. In the dog it developed smoothly to unite with diaphysis. In the male monkey it developed generally well with the cessation of growth during the period from three years and a half to five years.

Proximal epiphysis of ulna This ossification center developed without a hitch in all species except the rat. In the case of the rat it developed acceleratedly after four weeks, but was found to proceed only by one step from 5 th to 6 th step within the period from four weeks to nine weeks. Although it developed again after 6 th step, it stopped at 9 th step. In the mouse, the union seemed to complete at thirteen weeks, whereby a slight trace of the epiphysial cartilage line remained.

Distal epiphysis of ulna In the mouse and rat, the development was temporarily stopped for the period from three to five weeks. Thereafter, it developed up to the incomplete status of $8-9$ th step in the mouse, and of 9 th step in the rat, respectively, where they remained inactive. In the female monkey, the proceeding of this epiphysis lagged behind other centers for the period of two to five years. In the male monkey the complete union occurred latest of all other centers at seven years.

Proximal epiphsis of femur This ossification center developed without a hitch in all species. In the rat, the epiphysial cartilage line was observed even at one hundred and four weeks old.

Distal epiphysis of femur This portion developed smoothly as well as the proximal epiphysis of femur in all species.

Proximal epiphysis of tibia In all species, this ossification center developed smoothly to become united to its shaft. The time of the union was usually late. Ho- 
wever in the mouse, it remained at the 8 th step at the age of twenty seven weeks. In the dog, the epiphysis had a tendency to fall behind the other centers of the hind limb.

Distal epiphysis of tibia This epiphysis developed normally in each species. After the 6 th step in the mouse, its development was speedy.

Proximal epiphysis of fibula This epiphysis appeared latest among various epiphyses of all species, though the subsequent development was normal. However, in the dog and the monkey, its development was lagged up to the 5 th to 6 th step when compared with other species. Both in the mouse and the rat there was an incomplete union of these epiphyses, which remained at the 7 th step in the mouse, at 8-9 step in the rat. The epiphysis of the mouse was observed to remain in the immature status.

Distal epiphysis of fibula The development of this center was smooth and normal in each species, although the data of the mouse was lacking.
The sequence of appearance and union of each secondary ossification center showed a definite constancy with each species and was recognized to have a common chracter among the four species with a few exceptions as shown in Table 2. With regard to the sequence of appearance, the secondary ossification centers observed at the relatively early time were the proximal and distal epiphyses of humerus, the distal epiphysis of radius, the distal epiphysis of femur and both the proximal and distal epiphyses of tibia. Those observed at relatively late time were the supraglenoid tubercle, the proximal epiphysis of radius, both the proximal and distal epiphyses of ulna, the proximal epiphysis of femur and both the proximal and distal epiphyses of fibula. With regard to the sequence of union, the epiphyses observed at relatively early time were the supraglenoid tubercle, the distal epiphysis of humerus, both the proximal and distal epiphyses of radius, the proximal epiphysis of ulna, the distal epiphysis of tibia and the proximal epiphysis of fibula. In the midperiod, there

Table 2. Common sequence of appearance and union of various ossification centers for the mouse, rat, dog and monkey.

\begin{tabular}{ll}
\multicolumn{1}{c}{ Early period } & Appearance \\
Humerus p. & \multicolumn{1}{c}{ Late period } \\
Humerus d. & Supraglenoid tubercle (mouse) \\
Radius d. (mouse, dog) & Radius p. \\
Femur d. & Ulna p. (mouse) \\
Tibia P. & Femur p. (dog) \\
Tibia d. & Fibula. p. \\
& Fibula d. \\
& Union \\
Early period & Middle period \\
Supraglenoid tubercle & Femur p. \\
Humerus d. (dog) & Femur d. \\
Radius p. (dog) & Tibia. p. \\
Radius d. (rat) & \\
Ulna p. & \\
Tibia d. & \\
Fibula p. & \\
\hline
\end{tabular}

( ) indicates exception, P., proximal epiphysis ; d., distal epiphysis. 
were both the proximal and distal epiphyses of femur and the proximal epiphysis of tibia. Those united at relatively late time were the distal epiphysis of ulna and the distal epiphysis of fibula.

From the above, it was suggested that the respective secondary ossification centers in each species had almost the same growth pattern. In order to compare among the four species the whole process of maturation of the secondary ossification centers, a method proposed by Acheson $[1$, 2] was employed. Consequently, a simple pattern consisting of three straight lines with different slopes was observed to be common with all species as shown in Fig. 2. The three stages as indicated by the three lines were as follows. The first
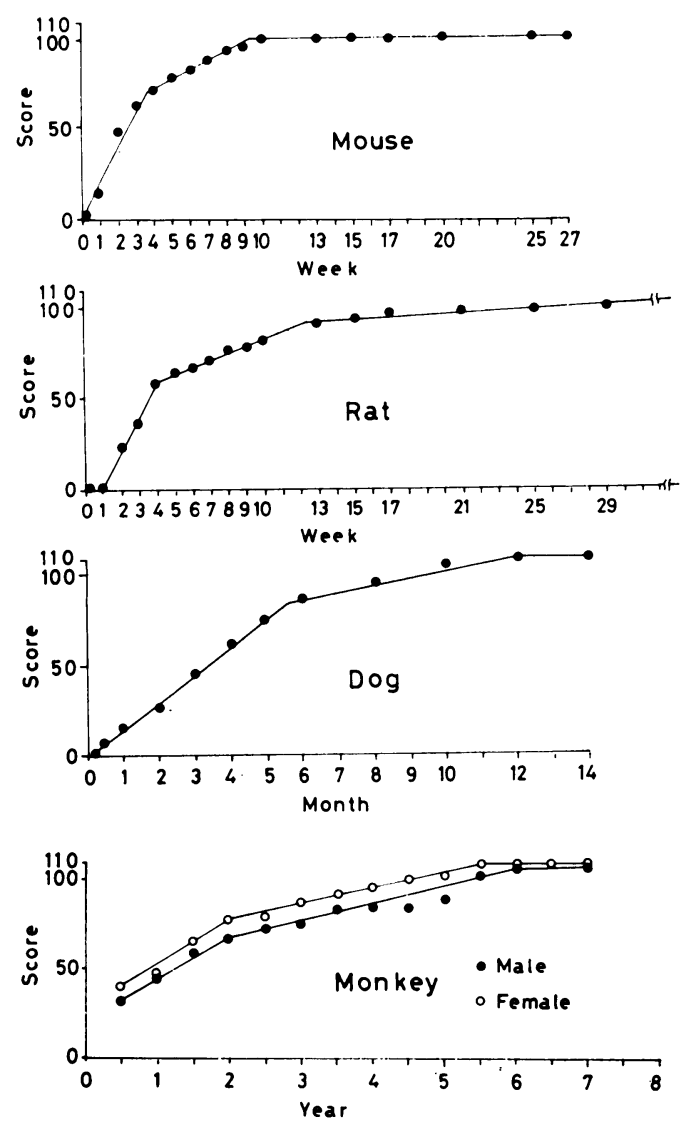

Fig. 2 Comparison of the pattern with the maturation process of the secondary ossification center in mouse, rat, dog and monkey. stage $\cdots . .$. the period when the bone scores increased at high late, the second stage...... the period when the bone scores increased gradually, and the third stage......the period when the bone scores reached a plateau. The bone scores at the first intersecting points between the first and the second stage were within the range from 60 to 80 for all species. At this point, all the secondary ossification centers found to reach the 5 th step of the criteria [11]. Those at the second intersecting points between the second and the third stage were within the range from 90 to 110 . In the third stage, the total bone scores in the mouse and the rat were less than the full scores because of the several epiphyses showing an incomplete union to diaphysis $[5,7]$. Noteworthy is the line in the third stage of the rat which showed a very slight increase over that of the dog and monkey which reflects the fact that the maturation lagged slightly in the rat.

As shown in Fig. 2, the period of the first stage for the mouse, rat, dog and monkey were 3 days to 3.5 weeks, 1 to 4 weeks, 1 week to 5.5 months and 20 weeks of gestaion age to 2 years, those for the second stage were 3.5 to 9.5 weeks, 4 to 12.5 weeks, 5.5 to 12 months, and 2 to 6 years (male monkey) and 2 to 5.5 years (female monkey), respectively.

\section{Discussion}

From the review of the development of each secondary ossification center in four species of animals, it can be stated that the these species share 'in general' a common pattern in the sequence of appearance of secondary ossification centers and their union to diaphysis and that the common pattern in more evident in the sequence of union than in that of appearance. According to Stevenson [13] who reported on the human bones, the same sequence of union may be found quite generally throughout the mammalian forms as chractristic to the mammalian species. His observation seems justifiable by our 
present result from four experiment animals species. The confirmation of this theory might facilitate the analyses of effects which were observed from experiments using some animal species.

It is considered to be important to standardize an experimental condition in which several aninial species are used for the comparative studies. In our previous studies $[5,6,7]$, this principle has always been followed. The materials selected for observation were the long bones in the extremities which were similar in number and morphological chracteristic and which were suitable as indicator not only in small animals but also in large ones. The radiographic technique was available to estimate the status of developmental ossification centers in all species. The criteria proposed on man by Ohwada and Sutow [11] was also applicable in animal species. In addition, the introduction of this common criteria into the analysis appeared successful in making the best use of the method by Acheson $[1,2]$, which was employed to facilitate comparison of maturation processes of the secondary ossification centers in all species. This method has been recognized even only partly for man to be a useful means to simplify comprehensively the assessment of bone development by other investigators $[10,14,15,16]$.

With regard to the animal's data, the growth pattern of the secondary ossification centers of the fore limbs and of the hind limbs was separately examined in each species. As compared with the growth pattern in the case of the fore and the hind limbs together, the pattern was observed to reveal almost no difference in either of the fore or the hind limbs.

The results of calculation as was made in accordance with the method proposed by Acheson are given in Fig. 2 in which a common pattern is shown. In all species, the whole process of maturation of the secondary ossification centers of long bones in the extremities was observed to consist of three biological stage. Accordingly, as

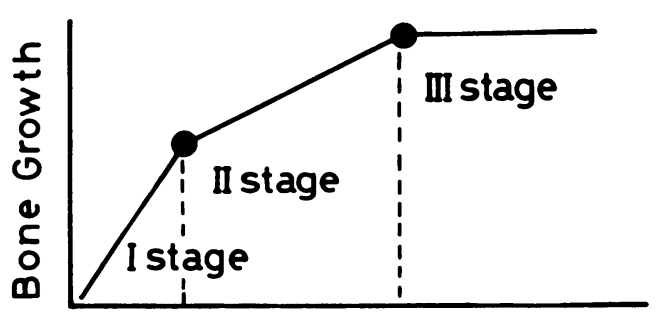

Age

Fig. 3 Schematic representation of the maturation processes of secondary ossification centers in common with mouse, rat, dog and monkey.*

*In these species, the maturation processes are generally divided into the three biological stages ; I stage..... appearance and subsequent acute developmental period, II stage...... gradual developmental period, III stage $\cdots . .$. complete union period.

shown in Fig. 2, there are two intersecting points for each species. The respective bone scores for these intersecting points were approximately constant for each species as pointed out in the results. The developmental condition of secondary ossification centers in each stage was considered, therefore, to be almost same for the species examined. The fact that each stage showed a straight line may serve to correlate the status of the developmental bone among the four animal species.

In Fig. 2, the species differences related to the status of development of bone at the birth time were indicated. This fact as well as the apparent differences in the time of intersecting points for each species indicates that the chronological age counted from the birth time is not a useful parameter to compare status of development among several species, but that correspondence of the ages based on biological development are important.

The biological significance of three stages as shown diagrammatically in Fig. 3 may be interpreted as follows : the first stage corresponds to the appearance of the secondary ossification centers and its rapid development in the early period; the second stage to the subsequent moderate 
development; and the third stage to the completion of union.

It is concluded that the maturation process of each secondary ossification center in the four species examined in this shows a definite pattern of development consisting of three biological stages in bone development. This result might be put to practical use such as to chek the status of maturity for animal breeding or to examine the toxicity of various substances on the bones of several animal species.

\section{Acknowledgement}

The authors would like to thank professor H. Ichiki, Department of Veterinary Surgery, Nippon Vetrinary and Zootechnical colloge for granting his data on beagle dog [8] to be concluded in this study.

\section{References}

[1] Acheson, R. M. (1957). The oxford method of assessing skeletal maturity. Clinical orthopaedics, 10, 19-39.

[2] Acheson, R.M.(1954). A method of assessing skeletal maturity from radiographs. A report from the oxford child health survey. J. Anat., 88, 498-508.

[3] Dawson, A. B. (1925). The age order of epiphyseal union in the long bones of the albino rat. Anat.Rec., 31, 1-17.

[4] Donaldson, H. H. (1924). The rat : data and reference tables, 2nd ed. pp. 37-49. philadelphia.

[ 5] Fukuda, S., and Matsuoka, O. (1977). Comparative studies on bone growth in experimental animals. I. Bone growth and ossification in mice. Exp. Anim., 26, 103-113.

[6] Fukuda, S., Cho, F., and Honjo, S. (1978). Bone growth and development of secondary ossification centers of extremities in the cynomolgus monkey (Macaca fascicularis). Exp. Anim., 27, 387-397.

[7] Fukuda, S., and Matsuoka, O. (1979). Maturation process of secondary ossification centers in the rat and assessment of bone age. Exp. Anim., 28, 1-9.

[8] Ichiki, H. (1976). Radiographic studies on the normal skeleton growth. In Studies on Beagles for Research in Japan, pp. 119-174. Fukui, M., Tomoda, I., and Ueda, K. (edit.), Soft Science, Inc., Tokyo.

[9] Johnson, M. L. (1933). The time and order of appearance of ossification centers in albino mouse. Am. J. Anat., 52, 241-271.

[10] Muramoto, K. (1965). A method of assessing the skeletal age of the elbow joint. J. Japan. Orthopaedic Asso., 38, 939-950.

[11] Ohwada, K., and Sutow, W. W. (1953). Criteria of skeletal maturation (bone age standard) in Japanese healthy children from 6 to 19 years old. Japan. J. Pediat., 6, 738-746.

[12] Parcher, J. W., and Wlliams, J. R. (1970). Ossification. In The Beagle as an Experimental Dog, pp. 158-161. Andersen, A. C. (edit.), The Iowa State Univ. Press Inc., Iowa. U. S. A.

[13] Stevenson, P. H. (1924). Age order of epiphyseal union in man. Am. J. Anthrop., 7, 53-93.

[14] Sugiura, Y., and Nakazawa, O. (1972). Bone-age Roentgen Diagnosis of Skeletal Development. Chugai-igaku Co. Tokyo.

[15] Sugiura, Y., Nakazawa, O., Kunishima, Y., Aoki M., and Ito. H. (1961). A method of assessing the skeletal age ( 2 nd report). J. Japan. Orthopaedic Assoc., 35, 429-439.

[16] Tajima, T. (1964). A method of assessing skeletal maturity of the knee joint. J. Japan. Orthopaedic Assoc., 38, 791-804.

[17] van Wagenen, G., and Asling, C. W. (1958). Roentgenographic estimation of bone age in the rhesus monkey (Macaca mulatta) Am. J. Anat., 103, 163186.

[18] Washburn, S. L. (1943). The sequence of epiphyseal union in old world monkeys. Am. J. Anat., 73, 339360 .

\title{
マウス，ラット，イヌおよびサルにおける四肢長骨の 骨端核の発育に関する比較研究
}

\author{
福田俊・松阙理
}

放射線医学総合研究所障害基礎研究部

マウス (C3H), ラット (Wistar) およびサル (Cynomolgus）の四肢長骨の発育を観察した結果はすでに本 誌に報告した。本論文ではこれらの結果に同一方法で研 究されたビーグル犬に関する論文を引用し, これら 4 種
類の実験動物の四肢長骨の発育に関する比較検討を行な った。

各動物種におけるそれぞれの四肢長骨の骨端核の出現 から融合までの発育の様相は共通していた。そこで各動 
物種の骨端核の全発育過程を単純化かつ抱括的に比較す るために, 各測定時点ごとに評価基準にもとづいて得た それぞれの骨端核の骨点数を総和し，それを各動物の暦 年令に対してプロットする方法を用いた。その結果, 直

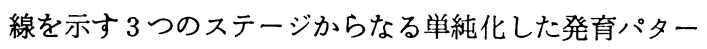
ンが各動物に共通して得られた。これらの3つのそれぞ れのステージはどの動物種においても生物学的に同じ意 味をもつと解釈された。すなわち第 1 ステージは骨端核
の出現および初期の急速な発育を, 第 2 ステージはその 後から融合完成までの緩徐な発育を，第 3 ステージは融 合完成以後を，それぞれ示すと考えられた。

以上のことから，マウス，ラット，1又およびサルの 四肢長骨の骨端核の発育過程は, 3 つの生物学的ステー ジからなる共通した発育パターンを示し, かつ各動物の それぞれのステージは相互に対応していることが知られ た。 